\title{
Multiple Endocrine Neoplasia Type 1
}

National Cancer Institute

\section{Source}

National Cancer Institute. Multiple Endocrine Neoplasia Type 1. NCI Thesaurus. Code C3225

Multiple endocrine neoplasia caused by inactivation of the tumor suppressor gene MEN-

1. Patients may develop hyperparathyroidism and parathyroid gland adenomas, pituitary gland adenomas, pancreatic islet cell neoplasms, and carcinoid tumors. 